\title{
KECEMASAN TENAGA KESEHATAN DALAM MENGHADAPI COVID-19
}

\author{
Rizka Sofia $^{2}$, Juwita Sahputri ${ }^{2}$ \\ ${ }^{1}$ Bagian Parasitologi, Fakultas Kedokteran Universitas Malikussaleh, Aceh Utara \\ ${ }^{2}$ Bagian Parasitologi, Fakultas Kedokteran Universitas Malikussaleh, Aceh Utara \\ Corresponding Author: drrizkasofia@gmail.com
}

\begin{abstract}
Abstrak
COVID-19 adalah penyakit menular yang disebabkan oleh tipe baru coronavirus dengan gejala umum demam, kelemahan, batuk, kejang dan diare. Kejadian kasus Covid-19 terus bertambah dari hari ke hari sehingga petugas kesehatan sebagai garis depan semakin tertekan karena meningkatnya beban kerja, mengkhawatirkan kesehatan mereka, dan keluarga. Penelitian ini bertujuan untuk mengetahui pengaruh faktor risiko status keluarga, pengetahuan, ketersediaan alat pelindung diri, dan kejujuran pasien terhadap kecemasan kecemasan tenaga kesehatan di Kota Lhokseumawe dalam menghadapi Covid-19. Jumlah sampel dalam penelitian ini sebanyak 120 tenaga kesehatan yang bertugas di seluruh puskesmas di Kota Lhokseumawe. Metode analisis data menggunakan analisis regresi logistic ordinal. Hasil analisis logistic ordinal menunjukkan bahwa status keluarga secara signifikan tidak berpengaruh terhadap kecemasan tenaga kesehatan. Sementara, tingkat pengetahuan, ketersediaan APD, dan kejujuran pasien secara parsial berpengaruh secara signifikan terhadap kecemasan tenaga kesehatan dalam menghadapi Covid-19 dengan nilai odds ratio masing masing sebesar $(7,86)$, $(9,86)$, dan $(5,45)$. Faktor risiko ketersediaan APD mempunyai kecenderungan yang paling kuat $(9,86)$ dalam mempengaruhi kecemasan tenaga kesehatan di Kota Lhokseumawe dalam menghadapi Covid-19.
\end{abstract}

Kata Kunci: alat pelingdung diri, kecemasan, kejujuran pasien, status keluarga, pengetahuan.

\section{Health Personnel Anxiety In Facing Covid-19}

\begin{abstract}
Covid-19 is an infectious disease caused by a new type of coronavirus with common symptoms of fever, weakness, cough, seizures and diarrhea. The incidence of Covid-19 cases continues to increase day by day so that health workers as the front line are increasingly depressed due to increased workloads, worrying about their health, and their families. This study aims to determine the effect of risk factors for family status, knowledge, availability of personal protective equipment, and patient honesty on the anxiety of health workers in Lhokseumawe City in dealing with Covid-19. The number of samples in this study were 120 health workers who served in all health centers in Lhokseumawe City. Methods of data analysis using logistic regression analysis ordinal. The results of ordinal logistic analysis showed that family status had no significant effect on the anxiety of health workers. Meanwhile, the level of knowledge, availability of PPE, and honesty of patients partially have a significant effect on the anxiety of health workers in dealing with Covid-19 with odds ratio values of (7.86), (9.86), and (5.45), respectively. The risk factors for the availability of PPE
\end{abstract}


have the strongest tendency (9.86) in influencing the anxiety of health workers in Lhokseumawe City in dealing with Covid-19.

Keywords: personal protective equipment, anxiety, patient honesty, family status, knowledge.

\section{Pendahuluan}

Covid-19 adalah penyakit menular yang disebabkan oleh tipe baru coronavirus dengan gejala umum demam, kelemahan, batuk, kejang dan diare. ${ }^{1,2}$ Gejala paling umum yang terjadi pada penyakit SARS-CoV-2 yang disebut Covid-19 adalah demam, lemas, batuk, dan diare. ${ }^{3,4}$ Gejala lainnya adalah sesak napas, gejala ini merupakan sindrom gangguan pernapasan akut. ${ }^{5}$ Pada Desember 2019, sejumlah pasien dengan pneumonia misterius dilaporkan untuk pertama kalinya di Wuhan, Cina. ${ }^{6}$ Virus ini telah dinamai sindrom pernapasan akut parah coronavirus 2 (SARS-CoV-2) dan dapat bergerak cepat dari manusia ke manusia melalui kontak langsung. ${ }^{7,8}$

Pada Desember 2019, kasus pneumonia misterius pertama kali dilaporkan di Wuhan, Provinsi Hubei. Sumber penularan kasus ini masih belum diketahui pasti, tetapi kasus pertama dikaitkan dengan pasar ikan di Wuhan. ${ }^{9}$ Sejak 31 Desember 2019 hingga 3 Januari 2020 kasus ini meningkat pesat, ditandai dengan dilaporkannya sebanyak 44 kasus. Tidak sampai satu bulan, penyakit ini telah menyebar di berbagai provinsi lain di China, Thailand, Jepang, dan Korea Selatan. ${ }^{10}$

Jumlah kasus Covid-19 di dunia per tanggal 22 Juli 2020 berjumlah 14.562 .550 kasus dengan peningkatan kasus baru sebanyak 213.637 kasus dan jumlah kematian sebanyak 607.781 kasus. ${ }^{11}$ Covid-19 pertama dilaporkan di Indonesia pada tanggal 2 Maret 2020 sejumlah dua kasus. ${ }^{11}$ Data per tanggal 22 Juli 2020 menunjukkan kasus yang terkonfirmasi berjumlah 91.751 kasus dengan peningkatan kasus baru berjumlah 1.882 kasus dan 4.459 kasus kematian. ${ }^{12}$ Menurut data dari Pemerintah Provinsi Aceh (2020), jumlah penderita yang terkonfirmasi positif Covid-19 di Provinsi Aceh per tanggal 22 Juli 2020 sebanyak 151 kasus dengan penambahan 2 kasus baru dengan jumlah kematian sebanyak 9 orang. Jumlah penderita terkonfirmasi positif Covid-19 di Kota Lhokseumawe sebanyak 8 orang dengan jumlah kematian sebanyak 1 orang. ${ }^{13}$

Kejadian kasus Covid-19 terus bertambah dari hari ke hari sehingga petugas kesehatan sebagai garis depan semakin tertekan karena meningkatnya beban kerja, mengkhawatirkan kesehatan mereka, dan keluarga. ${ }^{14}$ Satu hal yang dapat menyebabkan petugas kesehatan akan mengalami peningkatan kecemasan. Petugas kesehatan berisiko mengalami gangguan psikologis dalam merawat pasien Covid-19 karena perasaan depresi, penyebab utamanya 
adalah perlindungan diri yang masih kurang dari kebutuhan petugas kesehatan. ${ }^{15}$ Ketersediaan alat pelindung diri untuk petugas kesehatan masih kurang, sehingga banyak petugas kesehatan telah terpapar virus dan beberapa bahkan meninggal. ${ }^{16}$ Respon psikologis yang dialami oleh petugas kesehatan terhadap pandemi penyakit menular semakin meningkat karena disebabkan oleh perasaan cemas tentang kesehatan diri sendiri dan penyebaran keluarga. ${ }^{14}$ Kecemasan adalah kekhawatiran yang tidak jelas dirasakan oleh seseorang dengan perasaan tidak pasti dan tidak berdaya. ${ }^{17}$ Rasa panik dan rasa takut merupakan bagian dari aspek emosional, sedangkan aspek mental atau kognitif yaitu timbulnya gangguan terhadap perhatian, rasa khawatir, ketidakteraturan dalam berpikir, dan merasa binggung. ${ }^{18}$ Sehingga dari kejadian Covid-19 ini tenaga kesehatan merasa tertekan dan khawatir.

Penelitian Cheng (2020) menyatakan bahwa dari 13 partisipan mengalami kecemasan karena persediaan pelindung belum terpenuhi saat melakukan tindakan kepada pasien. ${ }^{14}$ Tenaga kesehatan merupakan kelompok yang sangat rentan terinfeksi Covid-19 karena berada di garda terdepan penaganan kasus, oleh karena itu mereka harus dibekali APD lengkap sesuai protokol dari WHO sehingga kecemasan yang dialami berkurang. Penyebab tenaga kesehatan mengalami kecemasan yakni tuntutan pekerjaan yang tinggi, termasuk waktu kerja yang lama jumlah pasien meningkat, semakin sulit mendapatkan dukungan sosial karena adanya stigma masyarakat terhadap petugas garis depan, alat perlindungan diri yang membatasi gerak, kurang informasi tentang paparan jangka panjang pada orang-orang yang terinfeksi, dan rasa takut petugas garis depan akan menularkan Covid-19 pada teman dan keluarga karena bidang pekerjaannya. ${ }^{19}$

Respon psikologis yang dialami oleh tenaga kesehatan terhadap pandemi Covid-19 ini menjadi meningkat karena disebabkan oleh perasaan cemas terhadap kesehatan sendiri dan penyebaran terhadap keluarga. Inilah yang menjadi salah satu faktor mereka mengalami kecemasan karena pada saat merawat pasien positif Covid-19 ataupun melakukan pemeriksaan pada masyarakat yang memiliki gejala Covid-19. Para tenaga kesehatan khawatir bahwa mereka akan menularkan virus korona Covid-19 kepada keluarga. ${ }^{20}$

Berbagai upaya yang dilakukan untuk memutus mata rantai penularan Covid-19 memerlukan kesadaran kolektif dan peran seluruh pihak. Permasalahan utama yang masih sering ditemukan dalam penanganan kasus Covid-19 adalah kejujuran pasien sendiri. Sejumlah kasus ketidakjujuran pasien Covid-19 soal riwayat kesehatannya saat mengakses layanan kesehatan di rumah sakit menyebabkan sejumlah petugas kesehatan, baik dokter dan perawat, terkena imbasnya. Ketidakjujuran pasien membahayakan bagi petugas atau tenaga 
medis yang menanganinya. Pasien yang tidak mengakui dirinya memiliki kemungkinan terinfeksi Covid-19 menyebabkan tenaga kesehatan mennjalankan tugasnya seperti penanganan pasien biasa, tanpa perlindungan diri sesuai protokol penanganan pasien Covid19.

\section{Metode}

Penelitian ini merupakan penelitian analitik observasional dengan rancangan potong lintang (cross sectional study), yaitu suatu rancangan penelitian yang mempelajari dinamika korelasi antara variabel independen dengan variabel dependen dengan melakukan pengukuran sewaktu. Penelitian ini dilakukan pada tenaga kesehatan yang bertugas di layanan primer milik pemerintah Kota Lhokseumawe.

Varibel dependen dalam penelitian ini yaitu tingkat kecemasan tenaga kesehatan dalam menghadapi Covid-19 yang diukur dengan menggunakan instrumen Hamilton Anxiety Rating Scale (HARS). HARS terdiri dari 14 item pertanyaan untuk mengukur tanda adanya kecemasan. Penentuan derajat kecemasan dengan cara menjumlahkan skor 1-14 dengan hasil: 1) Skor kurang dari 14: tidak ada kecemasan; 2) Skor 14-20: kecemasan ringan; 3) Skor 2127 : kecemasan sedang; 3) Skor 28-4 : kecemasan berat; 5) Skor 42-52 : kecemasaan berat sekali. Variabel independen dalam penelitian ini adalah status keluarga tenaga kesehatan, tingkat pengetahuan tenaga kesehatan, ketersediaan alat pelindung diri, dan kejujuran pasien. Variabel independen diukur dengan menggunakan instrument kuisioner yang diukur dengan skala nominal.

Metode analisis data yang digunakan dalam penelitian ini yaitu analisis regresi logistic ordinal untuk mengetahui faktor-faktor yang mempengaruhi kecemasan tenaga kesehatan dalam menghadap Covid-19.

\section{Uji Parallel Lines}

Uji parallel lines digunakan untuk menguji asumsi bahwa setiap kategori memiliki parameter yang sama atau hubungan antara variabel independen dengan logit adalah sama untuk semua persamaan logit. ${ }^{21}$ Asumsi parallel lines berarti besar odds ratio tidak terpengaruh oleh dimana variabel tak bebas dikotomisasikan. ${ }^{22}$ Kriteria pengujian hipotesis parallel lines yaitu apabila nilai $P$-value $>\alpha(5 \%)$ maka artinya asumsi parallel lines terpenuhi.

Uji Kesesuaian Model 
Uji kesesuaian model (Goodness of Fit) untuk melihat apakah model logistik ordinal yang didapat layak untuk digunakan atau tidak. Apabila nilai signifikansi goodness of fit $>\alpha$ (Pearson and Deviance $>0,05$ ) maka model yang terbentuk adalah fit atau layak digunakan. ${ }^{21}$ Uji Penduga Parameter Secara Simultan

Uji ini dilakukan dengan membandingkan model tanpa variabel prediktor yaitu dengan membandingkan nilai antara -2 log likelihood awal (intercept only) dengan dengan -2 log likelihood model final. Pengujian ini dilakukan untuk memeriksa pengaruh koefisien $\beta$ terhadap variabel tak bebas secara bersama-sama dengan menggunakan statistik uji. Kriteria pengujian yaitu apabila nilai signifikansi model fitting information $<0,05$, maka dapat dikatakan bahwa minimal terdapat satu variabel independen yang secara signifikan mempengaruhi variabel dependen.

\section{Uji Penduga Parameter Secara Parsial}

Pengujian ini dilakukan untuk menguji signifikansi koefisien $\beta$ secara parsial dengan menggunakan statistik uji Wald. Kriteria pengujiannya yaitu apabila nilai signifikansi Wald > 0.05, maka dapat dikatakan bahwa variabel independen tersebut secara signifikan mempengaruhi kecemasan tenaga kesehatan dalam menghadapi Covid-19.

\section{Hasil Penelitian}

\section{Uji Asumsi Parallel Lines}

Hipotesis nul pada pengujian ini adalah model menghasilkan koefisien regresi (slope) yang sama untuk semua kategori tingkat kecemasan tenaga kesehatan. Jika hipotesis nul gagal ditolak, maka asumsi parallel lines dapat dikatakan terpenuhi.

Tabel 1. Uji Parallel Lines

\begin{tabular}{lrrrrr}
\hline Model & $\begin{array}{c}\mathbf{- 2} \text { Log } \\
\text { Likelihood }\end{array}$ & Chi-Square & df & \multicolumn{1}{c}{ Sig. } \\
\hline Null Hypothesis & 37.389 & & & \\
General & 18.955 & 18.434 & 12 & .103 \\
\hline
\end{tabular}

Berdasarkan hasil uji pada tabel 1 di atas diperoleh nilai Chi-Square sebesar 18,434 dan $P$-value $>0,05$. Sehingga keputusan yang diambil adalah terima $\mathrm{H}_{0}$. Dengan demikian, pada tingkat kepercayaan $95 \%$ dapat dikatakan bahwa model yang dihasilkan memiliki koefisien regresi (slope) yang sama untuk semua kategori tingkat kecemasan tenaga kesehatan dan asumsi parallel lines terpenuhi. 


\section{Uji Kesesuaian Model (Goodness of Fit)}

Hipotesis nul dalam pengujian ini adalah model yang dihasilkan sesuai dengan data, dengan kata lain model tersebut layak untuk digunakan dalam penelitian. Jika hipotesis nul gagal ditolak, maka dapat dikatakan bahwa model yang didapatkan sesuai dengan data.

\section{Tabel 2. Uji Kesesuaian Model}

\begin{tabular}{|c|c|c|c|}
\hline & Chi-Square & df & Sig. \\
\hline Pearson & 28.110 & 32 & .664 \\
\hline Deviance & 21.096 & 32 & .930 \\
\hline
\end{tabular}

Berdasarkan tabel 2. di atas diperoleh nilai signifikansi Pearson dan Deviance $>0,05$ Maka, keputusan yang diambil adalah gagal tolak $\mathrm{H}_{0}$. Pada tingkat kepercayaan 95\% bahwa model regresi yang digunakan sesuai (fit) dengan data.

\section{Uji Penduga Parameter Secara Simultan}

Hipotesis nul dalam pengujian ini adalah tidak ada variabel independen yang berpengaruh secara signifikan terhadap tingkat kecemasan tenaga kesehatan. Jika hipotesis nul berhasil ditolak, maka dapat dikatakan bahwa minimal terdapat satu variabel independen yang secara signifikan mempengaruhi tingkat kecemasan tenaga kesehatan.

Tabel 3. Hasil Pengujian Secara Simultan

\begin{tabular}{lrrrrr}
\hline \multicolumn{1}{c}{ Model } & $\begin{array}{c}\mathbf{- 2} \text { Log } \\
\text { Likelihood }\end{array}$ & Chi-Square & Df & \multicolumn{1}{c}{ Sig. } \\
\hline Intercept Only & 79.657 & & & \\
Final & 37.389 & 42.269 & 4 & .000 \\
\hline
\end{tabular}

Berdasarkan hasil pengujian secara simutan pada tabel 3 di atas diperoleh nilai ChiSquare sebesar 42,269 dan $P$-value $<0,05$. Maka, keputusan yang diambil adalah tolak $\mathrm{H}_{0}$. Dengan demikian, pada tingkat kepercayaan $95 \%$ dapat dikatakan bahwa minimal terdapat satu variabel independen yang mempengaruhi tingkat kecemasan tenaga kesehatan secara signifikan.

\section{Uji Parameter Secara Parsial}


Hipotesis nul dalam pengujian ini adalah variabel independen tertentu secara paarsial tidak berpengaruh secara signifikan terhadap tingkat kecemasan tenaga kesehatan. Jika hipotesis nul berhasil ditolak, maka dapat dikatakan bahwa variabel independen tersebut secara parsial mempengaruhi tingkat kecemasan tenaga kesehatan dalam menghadapi Covid19 secara siginifikan.

Tabel 4. Hasil Pengujian Secara Parsial

\begin{tabular}{lrrrr}
\hline \multicolumn{1}{c}{ Variabel } & Estimate & Wald & Sig. & $\begin{array}{c}\text { Odds } \\
\text { Ratio }\end{array}$ \\
\hline Status Keluarga & .358 & .281 & .596 & \\
Tingkat Pengetahuan & 3.022 & 11.870 & .001 & 7,86 \\
Ketersediaan APD & -3.456 & 7.625 & .006 & 9,86 \\
Kejujuran Pasien & -2.298 & 18.062 & .000 & 5,45 \\
\hline
\end{tabular}

Berdasarkan table 4 di atas, diketahui bahwa dari empat variabel yang diduga mempengaruhi kecemasan tenaga kesehatan dalam menghadapi Covid-19, terdapat tiga variabel yang memiliki nilai p-value kurang dari 0,05 yaitu variabel tingkat pengetahuan, ketersediaan APD, dan kejujuran pasien. Artinya, pada tingkat kepercayaan $95 \%$ dapat dikatakan bahwa tingkat pengetahuan, ketersediaan APD, dan kejujuran pasien secara parsial berpengaruh secara signifikan terhadap kecemasan tenaga kesehatan dalam menghadapi Covid-19.

Setelah semua pengujian telah dilakukan, maka model regresi logistik ordinal dengan proportional odds yang terbentuk dapat ditentukan. Program pengolahan data dengan SPSS menyajikan arah yang terbalik pada output regresi logistik ordinal (Norusis, 2011). Oleh karena itu untuk penulisan model, arah koefisien parameter harus dibalik arahnya. Persamaan regresi logistik ordinal yang terbentuk yaitu:

$$
\begin{aligned}
& \operatorname{Logit}[\mathrm{P}(\mathrm{Y} \leq 1 \mid \mathrm{x})]=3,518-3,58 \mathrm{X}_{1}-3,022 \mathrm{X}_{2} *+3,456 \mathrm{X}_{3} *+2,298 \mathrm{X}_{4} * \\
& \operatorname{Logit}[\mathrm{P}(\mathrm{Y} \leq 2 \mid \mathrm{x})]=4,652-3,58 \mathrm{X}_{1}-3,022 \mathrm{X}_{2} *+3,456 \mathrm{X}_{3} *+2,298 \mathrm{X}_{4} * \\
& \text { *Signifikan pada tingkat kepercayaan } 95 \%
\end{aligned}
$$

\section{Pembahasan}

Hasil penelitian menunjukkan bahwa variabel status keluarga $\left(\mathrm{X}_{1}\right)$ mempuyai nilai Wald sebesar 0,281 dan $P$-value sebesar 0,596 $(>0,05)$ yang artinya pada tingkat kepercayaan 
95\% variabel status keluarga $\left(X_{1}\right)$ tidak berpengaruh yang signifikan terhadap kecemasan tenaga kesehatan. Berdasarkan persamaan di atas dipeoleh nilai estimate variabel status keluarga sebesar $-3,58$ artinya tenaga kesehatan yang belum menikah memiliki cenderungan mempunyai tingkat kecemasan yang lebih tinggi dibandingkan dengan tenaga kesehatan yang sudah menikah.

Variabel tingkat pengetahuan $\left(\mathrm{X}_{2}\right)$ mempunyai nilai Wald sebesar 11,870 dan P-value $0,001(<0,05)$ yang menunjukkan bahwa pada tingkat kepercayaan 95\% varabel tingkat pengetahuan $\left(\mathrm{X}_{2}\right)$ mempunyai pengaruh yang signifikan terhadap kecemasan tenaga kesehatan. Berdasarkan hasil pengolahan, didapatkan nilai odds ratio untuk variabel tingkat pengetahuan adalah sebesar $\exp (-3,022)=7,86$. Artinya, tenaga kesehatan yang tidak mempunyai tingkat pengetahuan yang baik tentang Covid-19 memiliki kecenderungan sebesar 7,86 kali lebih besar untuk memiliki tingkat kecemasan yang lebih tinggi dalam menghadapi Covid-19 dibanding tenaga kesehatan yang mempunyai tingkat pengetahuan yang baik tentang Covid-19 dengan asumsi semua variabel bebas lain dianggap konstan.

Semakin baik pengetahuan tentang covid yang dimiliki oleh tenaga kesehatan, maka akan semakin kecil tenaga kesehatan tersebut mengalami kecemasan. Hal ini dikarenakan dengan pengetahuan yang dimilikinya dapat menjadi acuan dalam meminimalkan terjadinya paparan Covid-19 dalam melayani pasien di puskesmas.

Variabel ketersediaan alat pelindung diri $\left(\mathrm{X}_{3}\right)$ mempunyai nilai Wald sebesar 7,625 dan $P$-value $0,006(<0,05)$ yang menunjukkan bahwa pada tingkat kepercayaan $95 \%$ varabel ketersediaan alat pelindung diri (X3) mempunyai pengaruh yang signifikan terhadap kecemasan tenaga kesehatan. Berdasarkan persamaan logistic ordinal di atas diperoleh nilai estimate variabel ketersediaan alat pelindung diri (APD) sebesar 3,456 dan nilai odds ratio sebesar 9,86. Artinya, tenaga kesehatan yang tidak mempunyai APD yang lengkap pada saat melayani pasien memiliki kecenderungan sebesar 9,86 kali lebih besar untuk memiliki tingkat kecemasan yang lebih tinggi dalam menghadapi Covid-19 dibanding tenaga kesehatan yang mempunyai APD dengan asumsi semua variabel bebas lain dianggap konstan.

Tenaga kesehatan merupakan kelompok yang sangat rentan terinfeksi Covid-19 karena berada di garda terdepan penaganan kasus, oleh karena itu mereka harus dibekali APD lengkap sesuai protokol dari WHO sehingga kecemasan yang dialami berkurang. Untuk itulah penyediaan alat pelindung diri yang tepat, sangat penting. ${ }^{23}$ Satu hal yang dapat menyebabkan petugas kesehatan akan mengalami peningkatan kecemasan, salah satunya adalah kurangnya Alat Pelindung Diri (APD) di tempat kerjanya. ${ }^{16}$ Petugas kesehatan berisiko mengalami 
gangguan psikologis dalam merawat pasien Covid-19 karena perasaan depresi, penyebab utamanya adalah perlindungan diri yang masih kurang dari kebutuhan petugas kesehatan. ${ }^{15}$ Dengan kurangnya ketersediaan alat pelindung diri lengkap menurut protokol WHO, tenaga kesehatan cenderung memiliki gangguan kecemasan dibandingkan dengan alat pelindung diri sesuai kebutuhan. Sehingga faktor ketersediaan alat pelindung diri memiliki pengaruh $51,7 \%$ terhadap kecemasan tenaga kesehatan dalam upaya pencegahan Covid-19. ${ }^{24}$

Penelitian serupa menunjukkan bahwa dari 13 partisipan mengalami kecemasan karena persediaan pelindung belum terpenuhi saat melakukan tindakan kepada pasien. ${ }^{14}$ Fasilitas alat pelindung diri kurang memadai bagi tenaga perawat yang bekerja dilingkungan kesehatan fisik akut, mereka merupakan kelompok yang sangat rentan terinfeksi Covid-19 karena berada di garda terdepan penaganan kasus, oleh karena itu mereka harus dibekali alat pelindung diri lengkap sesuai protokol dari WHO sehingga kecemasan yang dialami berkurang. ${ }^{25}$ Penelitian lain dari Kanada menyatakan bahwa 3 fungsi alat pelindung diri yakni untuk tetesan dan tindakan pencegahan kontak, untuk tindakan pencegahan melalui udara, tetesan, dan kontak umum, serta untuk mereka yang melakukan atau membantu dengan prosedur medis penghasil aerosol berisiko tinggi. ${ }^{23}$

Variabel kejujuran pasien $\left(\mathrm{X}_{4}\right)$ mempunyai nilai Wald sebesar 18,062 dan P-value $0,00(<0,05)$ yang menunjukkan bahwa pada tingkat kepercayaan 95\% varabel kejujuran pasien $\left(\mathrm{X}_{4}\right)$ mempunyai pengaruh yang signifikan terhadap kecemasan tenaga kesehatan. Berdasarkan hasil pengolahan, didapatkan nilai odds ratio untuk variabel kejujuran pasien adalah sebesar $\exp (2,298)=5,45$. Artinya, semakin tidak jujurnya pasien dalam memberikan informasi kepada tenaga kesehatan, maka kecenderungan tenaga kesehatan mengalami kecemasan sebesar 5,54 kali. Ketidakjujuran pasien ketika berobat atau mengenai kronologi penyakit, dianggap menjadi salah satu pemicu semakin banyaknya perawat atau dokter yang terinfeksi Covid-19 di Indonesia. Kejujuran pasien dalam memberikan informasi kepada tenaga kesehatan pada saat mendapatkan pelayanan kesehatan sangat penting. Sejumlah kasus ketidakjujuran pasien Covid-19 soal riwayat kesehatannya saat mengakses layanan kesehatan di rumah sakit menyebabkan sejumlah petugas kesehatan, baik dokter dan perawat, terkena imbasnya. Ketidakjujuran pasien membahayakan bagi petugas atau tenaga medis yang menanganinya. Pasien yang tidak mengakui dirinya memiliki kemungkinan terinfeksi Covid19 menyebabkan tenaga kesehatan mennjalankan tugasnya seperti penanganan pasien biasa, tanpa perlindungan diri sesuai protokol penanganan pasien Covid-19. 


\section{Kesimpulan dan Saran}

\section{Kesimpulan}

Faktor risiko keluarga tidak mempunyai pengaruh yang signifikan terhadap kecemasan tenaga kesehatan di Kota Lhokseumawe dalam menghadapi Covid-19. Sementara itu, faktor risiko tingkat pengetahuan, ketersediaan APD dan kejujuran pasien mempunyai pengaruh yang signifikan terhadap kecemasan tenaga kesehatan di Kota Lhokseumawe dalam menghadapi Covid-19. Faktor risiko ketersediaan APD mempunyai kecenderungan yang paling kuat dalam mempengaruhi kecemasan tenaga kesehatan di Kota Lhokseumawe dalam menghadapi Covid-19.

\section{Saran}

Diharapkan kepada pemerintah kota lhokseumawe untuk dapat memperhatikan alat pelindung diri (APD) di setiap puskesmas. Pasien-pasien harus memberikan informasi dengan jujur mengenai riwayat penyakitnya kepada tenaga kesehatan pada saat mendapatkan layanan kesehatan.

\section{Daftar Pustaka}

1. World Health Organization. The World Health Organization Declared The Coronavirus Outbreak A Global Public Health Emergency. Geneva: World Health Organization, 2020.

2. Repici, A., Maselli, R., Colombo, M., Gabbiadini, R., Spadaccini, M., Anderloni, A., Carrara, S., Fugazza, A., Di Leo, M., Galtieri, P. A., Pellegatta, G., Ferrara, E. C., Azzolini, E., \& Lagioia, M. Coronavirus (COVID-19) outbreak: what the department of endoscopy should know. Gastrointestinal Endoscopy 2020; 92(1), 192-197.

3. Remuzzi, A., \& Remuzzi, G. Health Policy COVID-19 and Italy: what next?. Health Policy 2020; 2, 10-13.

4. Guo, Y., Cao, Q., Hong, Z., Tan, Y., Chen, S., Jin, H., Yan, Y. The origin , transmission and clinical therapies on coronavirus disease 2019 (COVID-19) outbreak - an update on the status. Military Medical Research 2020; 7(11), 1-10

5. Prompetchara, E., Ketloy, C., \& Palaga, T. Immune responses in COVID-19 and potential vaccines: Lessons learned from SARS and MERS epidemic. Asian Pacific Journal of Allergy And Immunology 2020; 38(1), 1-9.

6. Phelan, A. L., Katz, R., \& Gostin, L. O. The novel coronavirus originating in wuhan, china: challenges for global health governance. JAMA 2020; 10.1001-1097. 
7. Li, Q., Guan, X., Wu, P., Wang, X., Zhou, L., Tong, Y., Ren, R., Leung, K., Lau, E., Wong, J. Y., Xing, X., Xiang, N., Wu, Y., Li, C., Chen, Q., Li, D., Liu, T., Zhao, J., Liu, M., Tu, W., ... Feng, Z. Early transmission dynamics in wuhan, china, of novel coronavirus-infected pneumonia. The New England Journal of Medicine 2020; 382(13), 1199-1207.

8. Rothe, C., Schunk, M., Sothmann, P., Bretzel, G., Froeschl, G., Wallrauch, C., Zimmer, T., Thiel, V., Janke, C., Guggemos, W., Seilmaier, M., Drosten, C., Vollmar, P., Zwirglmaier, K., Zange, S., Wölfel, R., \& Hoelscher, M. Transmission of 2019-nCoV infection from an asymptomatic contact in Germany. The New England journal of Medicine 2020; 382(10), 970-971.

9. Rothan, H. A., \& Byrareddy, S. N. The epidemiology and pathogenesis of coronavirus disease (COVID-19) outbreak. Journal of autoimmunity 2020; 109, 102433.

10. Huang, C., Wang, Y., Li, X., Ren, L., Zhao, J., Hu, Y., Zhang, L., Fan, G., Xu, J., Gu, X., Cheng, Z., Yu, T., Xia, J., Wei, Y., Wu, W., Xie, X., Yin, W., Li, H., Liu, M., Xiao, Y., ... Cao, B. Clinical features of patients infected with 2019 novel coronavirus in Wuhan, China. Lancet 2020; 395(10223), 497-506.

11. World Health Organization. Coronavirus Disease 2019 (COVID-19) Situation Report 184. Geneva: World Health Organization, 2020.

12. Gugus Tugas Percepatan Penanganan COVID-19. Data COVID-19. Jakarta: Gugus Tugas Percepatan Penanganan COVID-19, 2020. https://covid19.go.id/peta-sebaran.

13. Pemerintah Aceh. Info COVID-19. Aceh: Pemerintah Aceh, 2020. https://covid19.acehprov.go.id/ halaman/peta-sebaran

14. Cheng, H., Guo, J., Wang, C., Luo, F., Yu, X., Zhang, W., Li, J., Zhao, D., Xu, D., Gong, Q., Liao, J., Yang, H., Hou, W., \& Zhang, Y. Clinical characteristics and intrauterine vertical transmission potential of COVID-19 infection in nine pregnant women: a retrospective review of medical records. Lancet 2020; 395(10226), 809-815.

15. Lai, J., Ma, S., Wang, Y., Cai, Z., Hu, J., Wei, N., Wu, J., Du, H., Chen, T., Li, R., Tan, H., Kang, L., Yao, L., Huang, M., Wang, H., Wang, G., Liu, Z., \& Hu, S. Factors associated with mental health outcomes among health care workers exposed to coronavirus disease 2019. JAMA Network Open 2020; 3(3), e203976.

16. Ramadhan, A. Vitalnya ketersediaan APD untuk melindungi tenaga kesehatan. Jakarta., 2020. Diakses dari: https://www.antaranews.com 
17. Stuart, G. W. Prinsip dan Praktik Keperawatan Kesehatan Jiwa. Singapore: Elsevier, 2016.

18. Ghufron, M. N., \& Risnawita, R. Teori-teori psikologi. Yogyakarta: Ar- Ruzz Media. 2014.

19. IASC. Catatan tentang aspek kesehatan jiwa dan psikososial wabah COVID-19. 2020

20. Shanafelt, T., Ripp, J., \& Trockel, M. (2020). Understanding and addressing sources of anxiety among health care professionals during the COVID-19 pandemic. JAMA 2020; 10:1001-5893.

21. Yamin, Sofyan dan Kurniawan, Heri. SPSS Complete: Teknik Analisis Terlengkap dengan Software SPSS. Jakarta: Salemba Infotek, 2014.

22. Kleinbaum, D.G., \& Klein, M. Logistic regression: A self-learning text. 3rd Edition. New York: Springer Science, 2010.

23. Lockhart, S. L., Duggan, F. L. V, Wax, F. R. S., Saad, S., \& Grocott, H. P. (2020). Personal protective equipment (PPE) for both anesthesiologists and other airway managers : principles and practice during the COVID-19 pandemic. Canadian Journal of Anesthesia 2020; 67: 1005-1015.

24. Fadli, F., Safruddin, S,. Ahmad, A.S., Sumbara, S,. \& Baharuddin, R. Faktor yang mempengaruhi kecemasan pada tenaga kesehatan dalam upaya pencegahan covid-19. Jurnal Pendidikan Keperawatan Indonesia 2020; 6(1), p. 57-65.

25. Maben, J., \& Bridges, J. Covid-19: Supporting nurses' psychological and mental health. Journal of Clinical Nursing 2020; 29(10), 1423-1424. 